\title{
The Effect Of Organizational Culture, Education, And Compensation To Performance Of Civil Servant Employees In Secretariat Dprd Bantaeng District
}

\author{
Maryadi \\ STIE Nobel Indonesia Makassar, Indonesia \\ Email: ahmadmaryadi@gmail.com
}

\begin{abstract}
This study aims to analyze the influence of organizational culture, education, and compensation partially on the performance of employees in the Secretariat of the DPRD Bantaeng Regency. The research approach uses survey. Research respondents amounted to 85 people. Techniques used for data collection in this study are Interviews, Questionnaire, Documentation study. The results showed that organizational culture, education, and compensation have a significant effect on the performance of Bantaeng Regency DPRD Secretariat staff.
\end{abstract}

Keywords: Organizational Culture, Compensation

\section{$1.0 \quad$ Introduction}

Organizational culture has an impact on the efficiency and effectiveness of the organization. Strong organizational culture can shape an organization's identity that provides a competitive advantage compared to other organizations (Saggaf et al., 2014; Akib and Salam, 2016; Salam and Rosdiana, 2016). Organizational culture is a shared perception shared by members who distinguish the organization with other organizations. Organizational culture, therefore, is an important part of understanding the whole organization. Culture is an organizational value system and will affect how work is done and how employees behave. Individuals can be able and efficient without being dependent on others, but their behavior is not in accordance with organizational culture, then the person will not succeed in the organization. The strength of organizational culture will be evident from how employees perceive a culture that affects the behavior of members in the organization described as having high motivation, dedication, creativity, commitment, and satisfaction. The stronger the organizational culture, the higher the commitment that will ultimately sustain performance.

The life of everyday society is inseparable from the cultural bond created. Cultural ties reached by the people concerned, whether in the family, organization, business or nation. Culture differentiates society from one another in how to interact and act to complete a job. Culture binds members of community groups into a unified view that creates uniformity of behaving 
or acting. Along with the passage of time, culture must be formed within the organization and can also be beneficial in contributing to the effectiveness of the organization as a whole.

Each organization has its own characteristics, both in terms of goals, vision and mission and the diversity of resources (employees) owned (Holsapple and Joshi, 2001; Burke, 2017). Basically, every organization would want the best performance of all employees. The high performance of employees will make it easier for organizations to achieve organizational goals. To achieve success, a good role is needed for the organization or the employee itself. Organizations provide facilities in the form of educational and training activities, sending employees, are expected to contribute to the organization. Employees can be regarded as an organizational asset; then the organization needs to test and meet the needs of employees. A fundamental need for every employee wherever they are is a sense of security in living his role as an employee or his role as the source of the main breadwinner for his family. A person works because there is something to be accomplished and one hopes that the work activity he does will bring him to a state that is more satisfying than the previous situation.

Education and training is an attempt to improve employee performance in his current job or in any other occupation he holds today. Further explained that training is a systematic process to change employee behavior in an effort to improve organizational performance. Educational and training programs for human resources can be needed to create professional and qualified personnel to improve performance. Education and Training has a dual role for the employees concerned, on the one hand establishing the position in carrying out duties and functions and on the other side of career development on the position and higher positions are very possible.

The quality and ability of employees is influenced by the level of education, training, motivation, work ethic, mental and physical ability of the employees concerned. Education provides knowledge not only directly with the execution of the task, but also the foundation for self-development and the ability to utilize all existing means for the smooth implementation of the task. The higher the education, the higher the productivity of work. In reality, a person's performance will be different from others. In order for the performance of each employee to increase required a push or factor that can make the employee's performance as expected by the organization. Factors affecting the relative complex may be intrinsic factors (level of education, knowledge, skills, motivation, health, and experience) and extrinsic factors (compensation, work climate, leadership, work facilities, and social relations).

One of the main duties that need to be paid attention to human resources in the organization is to meet its welfare in the form of rewards for the work of an employee. Compensation is a term related to financial rewards received by people through their employment relationships with an organization. Compensation can basically be grouped into two groups, namely direct compensation, and indirect compensation. Direct compensation in the form of basic salary and variable salary, and indirect compensation in the form of allowances, Direct compensation the employee receives as a basic compensation is called the base salary. Salary is one of the things that encourage or motivate employees to work or serve the whole organization. Salaries and compensation factors in the form of performance allowances are still not optimal in the Secretariat of Bantaeng Regency DPRD. 


\subsection{Research Method}

This research approach uses survey research that takes a sample from one population and uses the questionnaire as main data gathering tool(Veal, 2017). Implementation of research conducted at Secretariat of Regency of Bantaeng Regency. The population used in this research is all staff of Secretariat of Bantaeng Regency DPRD which amounted to 85 people (Data of December 2017) covering ASN counted 24 people, and Honorary Staff counted 61 people. The sample is part of the number and characteristics possessed by the population. The sample selection in this study was conducted by using the saturated sampling method (census) by determining all the population as a total sample of 85 employees. Techniques used for data collection in this research are Interview, Questionnaire, documentation. Descriptive analysis is used to describe or describe organizational culture, education, and compensation and employee performance. In this analysis used table form and average value to clarify the description of variables.

\subsection{Result And Discussion}

\subsection{The Influence of Organizational Culture on Performance}

Description of t-test by using SPSS data analysis program ver. 15 it is known that the three independent / independent variables (X) significantly affect the performance of the Bantaeng Regency DPRD Secretariat staff, where the organizational culture variable (X1) with the count $2,412>\mathrm{t}$ table 1,993. Organizational culture (X1) is a set of assumptions or belief systems, values, and norms developed within organizations that serve as a behavioral guide for members to address external adaptation and internal integration issues. Indicators of organizational culture in this study include individual initiatives, risky action tolerance, direction, integration, and management support.

The value of organizational culture regression coefficient (X1) of 0.170 means there is a positive influence of organizational culture on the performance of the Secretariat staff of Bantaeng Regency DPRD of 0.170 so that if the score of organizational culture increases 1 point then it will be followed by the increase of employee performance score Secretariat of Bantaeng Regency DPRD equal to 0,170 points.

Based on the theory that has been presented in the previous chapter and the conclusions made by other researchers, it can be seen that the assumption that the organizational culture is a major determinant of the success of an organization's performance. The success of an organization to implement its organizational culture aspects or values can drive the organization to grow and develop sustainably. This is evident from the results of data processing using data analysis techniques through multiple linear regression formula, product moment, and the coefficient of determination described above.

\subsection{The Effect of Education on Performance}

Description of t-test by using SPSS data analysis program ever. 15 it is known that the three independent / independent variables (X) significantly affect the performance of the staff of the Secretariat of DPRD Bantaeng Regency, where the educational variable (X2) with the count 2.105 $>\mathrm{t}$ table 1.993. Education (X2) is a systematic process to improve the theoretical, conceptual, and employee moral skills that are useful for developing knowledge in order to 
work skillfully in accordance with responsibility in order to achieve organizational goals (Hasibuan, 2009). Educational indicators in this study include theoretical expertise, and conceptual skills, employee morale.

Education as a component that is expected to improve the work in the duties and responsibilities of employees in an organization. Education officer Secretariat of Bantaeng Regency DPRD most dominant is employees who have background Education Stara 1 (S-1). It illustrates that in terms of quality, human resources of employees have been good enough. One effort to meet the quality of human resources in every field of work is the suitability of education. The suitability of education in the field of work is carried out to coordinate the tasks of the current job description and show the relevance to the achievement of the more effective and efficient performance objectives. Thus the suitability of education to the employment field of employees becomes the basis for determination of organizational goals.

The value of education regression coefficient (X2) of 0.346 means there is a positive effect of education on the performance of the Secretariat staff of Bantaeng Regency DPRD of 0.346 so that if the score of education increases 1 point then it will be followed by an increase in the performance score of the Secretariat staff of Bantaeng Regency DPRD by 0,346 points. The results of this study support the previous theory proposed that education has a very important role in influencing employee performance as a systematic process to improve theoretical, conceptual, and employee morale skills that are useful for developing knowledge in order to work skillfully in accordance with responsibility in an effort to achieve organizational goals.

\subsection{The Effect of Compensation for Performance}

Description of t-test by using SPSS data analysis program ever. 15 it is known that the three independent / independent (X) variables significantly affect the performance of the Bantaeng Regency DPRD Secretariat staff, where the compensation variable (X3) with the t-sum 3.303 > t table 1.993. Compensation (X3) is an income in the form of money or goods directly or indirectly received by employees in return for services rendered to the organization (Aritonang, 2005: 2). The compensation indicators in this study are wages and salaries, incentives, benefits, and facilities.

The value of compensation regression coefficient (X3) of 0.707 means there is a positive effect of compensation on the performance of the Secretariat staff of the Regency of Bantaeng at 0.707 so that if the compensation score increases 1 point then it will be followed by the increase of the performance score of the Secretariat staff of Bantaeng Regency DPRD by 0,707 points. The results are in line with Nurul Hidayah's research, 2016, Title; The Effect of Compensation on Employee Performance through Job Satisfaction as Intervening Variable (Case Study on Employee of Finance and Accounting Department of Yogyakarta State University). Compensation has a positive effect on Employee Performance. This is shown in the results of a simple linear regression that has a value of $t$ count of 2.142 is greater than $t$ table of 1.991.Compensation has a positive effect on Employee Performance mediated by Job Satisfaction. This is shown in the results of simple linear regression that has at value of 6.595 is greater than $t$ table of 1.991 and the mediation coefficient 0.154 . So it can be concluded that Compensation has a positive effect on Employee Performance mediated by Job Satisfaction. 


\subsection{Organizational Culture Influence, Motivation and Compensation to Performance}

The description of F test, because the value of Fcount is 11,34, mean independent / independent variable $(\mathrm{X})$ which include organizational culture, education and compensation simultaneously have an effect on to the employee performance of Bantaeng Regency DPRD Secretariat can be said significant because from the test show that results Fhitung $=11.34$ greater than $\mathrm{F}$ table $=$ 2.70, or it can be said Ho rejected and Ha accepted.

Performance of employees is the degree of success of the performance of employees in carrying out their duties and responsibilities, including the achievement of targets work, the ability to carry out the work and the fulfillment of support received within the organization. Anwar Prabu (2009: 9) the meaning of performance actually comes from the words of job performance and also called the actual performance or work performance or actual achievement that has been achieved by an employee. Indicators in this research are quantity of work, quality of work, the time period of output and cooperation.

The value of determination coefficient ( $\mathrm{R}$ square) of 0.645 which can be interpreted that independent variable $(\mathrm{X})$ which includes organizational culture, education and compensation have contribution to the performance of Bantaeng Regency DPRD Secretariat staff of $64,5 \%$, while the rest equal to $35,5 \%$ influenced by other variables not included in this study.

Factors that affect the achievement of performance is a factor of ability (ability) and factors (motivation) which suggests that the motivation is formed from the attitude of an employee in the face of work situations. Mental attitude that encourages employees to try to achieve the maximum work performance that is ready psychologically (ready mentally, physically, goals, and situations). Performance of a company would be part of the performance of employees if the performance of one of the employees said to be bad or not in accordance with the expected then it can affect the performance of the entire organization that can result in achievement of the goals of the organization will be hampered. A company must have a way to improve performance in order to keep the performance up and up. The ways that a company must be able to stimulate the perpetrator of his company, in this case, the employee.

\subsection{The Most Dominant Variables of Performance}

Based on the result of standardized beta value, it is known that the variables covering organizational culture, education, and compensation which have the biggest influence on the performance of the staff of Bantaeng Regency DPRD Secretariat are the compensation variable (X3). This is in accordance with the opinion of Mathis and Jackson (2010: 49) that one-way management to improve job performance, motivate and improve employee job satisfaction is through compensation.

Compensation is indeed one of the motivations for the employees themselves to improve their performance. So the employees are competing to improve their creativity for the company. For those who can continue to improve their creativity, then the compensation will be increased along with the increased performance and creativity of these employees. But for those who have not been able to increase creativity, no compensation will be given an increase so that sometimes leads to frustration for the employees themselves and eventually the performance of employees is also declining. 


\subsection{Conclusion}

The organizational culture, education, and compensation partially have a positive and significant effect on the performance of Bantaeng Regency DPRD Secretariat staff, each with count 2,412>t table 1,993, with $t$ count 2,105> t table 1,993 and $t$ count 3,303>t table 1,993. Organizational culture, education, and compensation together have a positive and significant effect on the performance of the staff of Bantaeng Regency DPRD Secretariat, from the test show that the result of Fhitung $=11,34$ is bigger than $\mathrm{F}$ table $=2,70$ or it can be said Ho rejected and $\mathrm{Ha}$ accepted. The most dominant compensation variable influenced the performance of the staff of Bantaeng Regency DPRD Secretariat, as evidenced by the largest standardized beta value of 0.668 .

\section{REFERENCES}

Akib, H. and Salam, R. (2016) 'Analisis Kualitas Pelayanan Publik Berbasis Importance Performance Analysis (IPA) pada Kecamatan Kota Makassar', Jurnal Ilmiah Scientific Pinisi. Lembaga Penelitian UNM, 2(April 2016), pp. 16-20.

Burke, W. W. (2017) Organization change: Theory and practice. Sage Publications.

Holsapple, C. W. and Joshi, K. D. (2001) 'Organizational knowledge resources', Decision support systems. Elsevier, 31(1), pp. 39-54.

Saggaf, S. et al. (2014) 'Pelayanan Fungsi Administrasi Perkantoran Modern', Jurnal Ad'ministrare, 1(1), pp. 20-27.

Salam, R. and Rosdiana (2016) 'Penerapan Fungsi Administrasi Perkantoran Modern berbasis Daya Saing Organisasi dalam menyongsong MEA 2015.', in SEMINAR NASIONAL 'Revolusi Mental dan Kemandirian Bangsa Melalui Pendidikan Ilmu-Ilmu Sosial dalam Menghadapi MEA 2015' Himpunan Sarjana Pendidikan Ilmu-Ilmu Sosial Indonesia. Fakultas Ilmu Sosial Universitas Negeri Makassar, pp. 186-190.

Veal, A. J. (2017) Research methods for leisure and tourism. Pearson UK. 